\title{
Structural sensitivity of an asphalt pavement to asphalt binder content and mix design method
}

\author{
Sensibilidade estrutural de um pavimento asfáltico ao teor de ligante \\ asfáltico e o método de projeto da mistura
}

\section{Cássio Alberto Teoro do Carmo ${ }^{1}$, Géssica Soares Pereira ${ }^{2}$, Geraldo Luciano de Oliveira Marques ${ }^{3}$, Paulo Roberto Borges ${ }^{4}$}

${ }^{1}$ Huesker Ltda., São Paulo - Brazil, cassiocarmo@gmail.com

${ }^{2}$ Federal University of Viçosa, Minas Gerais - Brazil, gessicasoares.p@gmail.com

${ }^{3}$ Federal University of Juiz de Fora, Minas Gerais - Brazil, geraldo.marques@uff.edu.br

${ }^{4}$ Federal University of São João Del Rei, Minas Gerais - Brazil, paroborges@yahoo.com.br

\section{Recebido:}

25 de janeiro de 2021

Aceito para publicação:

11 de novembro de 2021

Publicado:

19 de novembro de 2021

Editor de área:

Francisco Thiago Sacramento

Aragão

\section{Keywords:}

Method of dosage.

Resilient modulus.

Asphalt binder design contents.

Structural sensitivity.

\section{Palavras-chave:}

Método de dosagem.

Módulo de resiliência.

Teores de projeto de ligante

asfáltico.

Sensibilidade estrutural.

DOI:10.14295/transportes.v28i4.2456

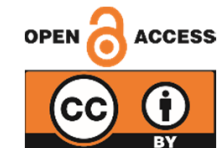

\begin{abstract}
The goal of this study was to analyze the structural sensitivity of a flexible pavement, whose asphalt layers underwent variations in its mechanical properties due to the asphalt binder content and the mix design method Marshall and Superpave. A variation of $\pm 0.5 \%$ within the optimum asphalt binder contents was used (service tolerance) considering possible permissible variations in the asphalt binder content during the asphalt mixture manufacturing process. The values of resilient modulus and indirect tensile strength (Brazilian test) of the resulting asphalt mixtures were applied to the reference pavement structure analyzed by the me-PADS software. The results show that the variations in the asphalt binder content and the asphalt mixtures design method influence the mechanical properties and corresponding structural responses of the pavement investigated: the asphalt layers designed by the Marshall method presented greater sensitivity to the variation in asphalt binder content, which may constitute a technical differential of asphalt mixtures designed by the Superpave method.
\end{abstract}

\section{RESUMO}

O objetivo deste estudo foi analisar a sensibilidade estrutural de um pavimento flexível, cujas camadas asfálticas sofreram variações em suas propriedades mecânicas em função dos teores de ligante asfáltico e dos métodos de dosagem, Marshall e Superpave. Foi considerada uma variação de $\pm 0,5 \%$ em torno do teor de projeto de ligante de asfalto, a fim de levar em consideração possíveis variações admissíveis do teor de ligante asfáltico durante o processo de produção da mistura asfáltica. Os valores de módulo resiliente e resistência à tração (ensaio brasileiro) das misturas resultantes foram aplicados à uma estrutura de pavimento de referência analisada pelo software mePADS. A partir da análise, conclui-se que as variações no teor de ligante de asfáltico e o método de projeto das misturas asfálticas influenciam as propriedades mecânicas e as respostas estruturais correspondentes do pavimento estudado: as camadas asfálticas projetadas pelo método Marshall apresentaram maior sensibilidade à variação no teor de ligantes de asfalto, o que pode constituir um diferencial técnico das misturas de asfalto projetadas pelo método Superpave.

\section{INTRODUCTION}

Hot mix asphalt (HMA) is the most common material used for surface course of asphalt pavements in different countries (Fritzen and Motta, 2016). The performance of asphalt pavement depends on asphalt binder properties, asphalt mixtures volumetric properties and 
external factors such as traffic volume and environment (Hamed, 2010), and aggregate properties (Mashaan et al., 2014). Thus, determining the optimum asphalt binder content assists in the selection of the asphalt mixture with the best volumetric characteristics, and stiffness and flexibility properties to avoid cracks due to fatigue and early plastic deformations, providing comfort and safety to the surface course throughout its service life.

There are several methods for designing asphalt mixtures, such as the Marshall, Hveem and Superpave methods. According to Al-Humeidawi (2016), the Marshall mix design method has been the most widely used method in many countries. This method is based on empirical experiments and has limitations in verifying the effects of traffic and its mechanical properties on pavement performance. For Ahmed et al. (2012) and many other researchers (Asi, 2007; Gouveia et al., 2007; Khedr and Saudy, 2016; Almeida Jr, 2018), the Marshall method is the most common in tropical countries.

The Superpave mix design method was developed in 1993 by the Strategic Highway Research Program (SHRP). According to Liu et al. (2018), it consists of three main stages, namely: (1) degree of performance of the asphalt binder, which depends on a range of temperature grades and adjustments according to traffic characteristics; (2) aggregate gradation criteria, with more restrictions than the Marshall method; (3) the asphalt mixing procedure, through which the field and performance conditions are simulated, consequently considering climatic and traffic conditions.

Regarding the asphalt binder content of asphalt mixtures, Karini et al. (2012), Jitsangiam et al. (2013), and Han et al. (2016) show that the Superpave method produces asphalt mixtures with lower contents of asphalt than those designed by the Marshall method, which might not reach the design density in field compaction, which can lead to problems of durability, such as premature cracking.

For possible variations in the optimum asphalt binder content during the asphalt mixture manufacturing process, the Brazilian service specification ES-031 (DNIT, 2006b) recommends the adoption of a service tolerance of $\pm 0.3 \%$ of the design value, there are several studies that use a variation of $\pm 0.5 \%$ in the asphalt binder content of asphalt mixtures for laboratory evaluation of the effect of this variation on the structural performance of asphalt mixtures (Vasconcelos et al. 2003; Marques, 2004; Netto and Reis, 2015; Sarsan and Husain, 2017).

In this study, we used variations of $\pm 0.5 \%$ around the optimum asphalt binder content, and quantified the measurable effects of this variation on the mechanical properties of the asphalt mixtures and corresponding structural responses of the pavements where they were applied. The variation in the asphalt binder content of asphalt mixtures can cause changes in the mechanical properties of the resulting asphalt layer and, consequently, in its structural performance comparatively to that initially foreseen. In this context, the main objective of this study is to evaluate the structural sensitivity of a reference pavement structure considering the possible influence of the permissible variation in the optimum asphalt binder content of the asphalt mixture on its mechanical properties (resilient modulus and tensile strength) and corresponding structural responses of the pavement, under specific loading conditions.

\section{MATERIAL AND METHODS}

\subsection{Materials}

In this research, a conventional asphaltic cement (AC) was used. This cement is classified 
according to penetration as CAP 50/70 produced by a private company, from the Gabriel Passos Refinery (REGAP), located in the city of Betim, state of Minas Gerais, Brazil.

The mineral aggregates used (gravel 1, gravel 0 and stone powder, with a maximum aggregate size of $25 \mathrm{~mm}, 12.5 \mathrm{~mm}$ and $<12.5 \mathrm{~mm}$, respectively) are of gneiss formation, also provided by a private company, which their quarry is in Ervália, in the state of Minas Gerais, Brazil.

\subsection{Methods}

\subsubsection{Asphalt mixtures Design}

For the production of the dense-graded asphalt mixtures, four granulometric compositions were defined according to the Brazilian specification ES-031(DNIT, $2006 \mathrm{~b}$ ). Two of these gradations were classified in the grading envelope C (Nominal Maximum Aggregate Size - NMAS $=12.5 \mathrm{~mm}$ ) and two in the grading envelope B (NMAS $=25.4 \mathrm{~mm}$ ).

The asphalt mixtures of compositions 1 and 2 were molded using the Marshall mix design method according to ME-043 test method (DNER, 1995) and were inserted into the grading envelopes $\mathrm{C}$ and $\mathrm{B}$, respectively. The compositions of asphalt mixtures 3 and 4 were produced by the Superpave mix design method (Level 1) according to the technical standard NBR 15897 (ABNT, 2010) and the North American recommendations present in AS-95-003 (FHWA, 1995), A-407 (SHRP, 1994) and R 35-14 (AASHTO, 2014) and were also included in the grading envelopes $C$ and $B$, respectively, so that the particle sizes meet the criteria set forth in the aforementioned North American technical standards for nominal maximum size of $19.0 \mathrm{~mm}$.

\subsubsection{Mechanical tests of asphalt mixtures}

After determining the asphalt binder design content for the asphalt mixtures according to the specifications of each design mix method used, some specimens were molded using the Marshall method of impact compaction and the Superpave method of gyratory compaction. In these specimens mechanical tests of resilient modulus (RM) and tensile strength (TS) were performed as per ME-135 (DNIT, 2018a) and ME-136 (DNIT, 2018b). In addition, specimens were molded by varying $\pm 0.5 \%$ of the asphalt binder design content of the analyzed asphalt mixtures in order to evaluate the sensitivity of these asphalt mixtures according to their mechanical properties and the possible effect of these on the structural performance of the reference pavement structure.

\subsubsection{Structural analysis}

A structural analysis was carried out for an empirically designed pavement structure adopted in this research. Regarding the wearing course, combinations of the design grading envelope $\mathrm{C}$ (wearing course) and B (binder course) of the Brazilian service specification ES-031 (DNIT, 2006b), the different compaction processes according to the design mix methods used and the contents of asphalt binder of the asphalt mixtures analyzed, were considered with the optimum asphalt binder contents and the variations of $\pm 0.5 \%$ around these values.

For the structural analysis, the me-PADS software was used, which is a South African software developed in 2001 based on linear multilayer elastic theory. The loading consists of up to ten loads, located at any point on the surface of the pavement and is used for five layers of the pavement (Maina et al. 2012). The sensitivity analyses of the variation in the resilient modulus of the studied asphalt mixtures were carried out for three levels of axle load, adopting 
a reference pavement structure consisting of wearing course, binder course, base and subgrade reinforcement, settled on the subgrade. The input data used in this software were: properties of the structural layers (thickness, Modulus of Elasticity and Poisson's coefficient), location and magnitude of the loads and coordinates of the points to determine the expected structural responses of the reference pavement structure.

For the input data concerning the layers of the reference pavement structure, the RM was considered equal to the Modulus of Elasticity (E), that is, a linear elastic analysis was performed. According to Ponte et al. (2014), when it is not possible to determine the Poisson's coefficient $(v)$, the recommendation is to use $v=0.30$, which was kept constant for the asphalt (surface course) and granular (base) layers in all analyses performed.

The selection of loading levels was based on the following considerations:

- $Q 1=80 \mathrm{kN}$ (8.2 tf): load corresponding to the standard axle of 18,000 lb, considered standard;

- $Q 2=98 \mathrm{kN}(10.0 \mathrm{tf})$ : maximum load allowed by Brazilian legislation for single axle dual wheels;

- $Q 3=118 \mathrm{kN}$ (12.0 tf): load with $20 \%$ above the maximum allowed, with $10 \%$ being the legal tolerance limit. The load of $20 \%$ above that permitted was adopted to show damages on paved roads when there is over-loading by commercial vehicle axles (80 $\mathrm{kN})$.

- Similarly, three corresponding levels of tire inflation pressure were used, namely:

- $\quad P 1=563 \mathrm{kPa}(80 \mathrm{psi})$ : standard pressure used in the experimental runway of AASHTO and standardized for the determination of deflection, according to test method ME-024 (DNER, 1994b), which has been adopted in several methods of flexible pavement structural design;

- $\quad P 2=633 \mathrm{kPa}(90 \mathrm{psi}):$ pressure considered average;

- $\quad P 3=703 \mathrm{kPa}(100 \mathrm{psi})$ : pressure considered high.

Figure 1 illustrates the reference pavement structure for the analysis of stresses and deformations in its structural layers and the single-axle load with two wheels applied on its surface.

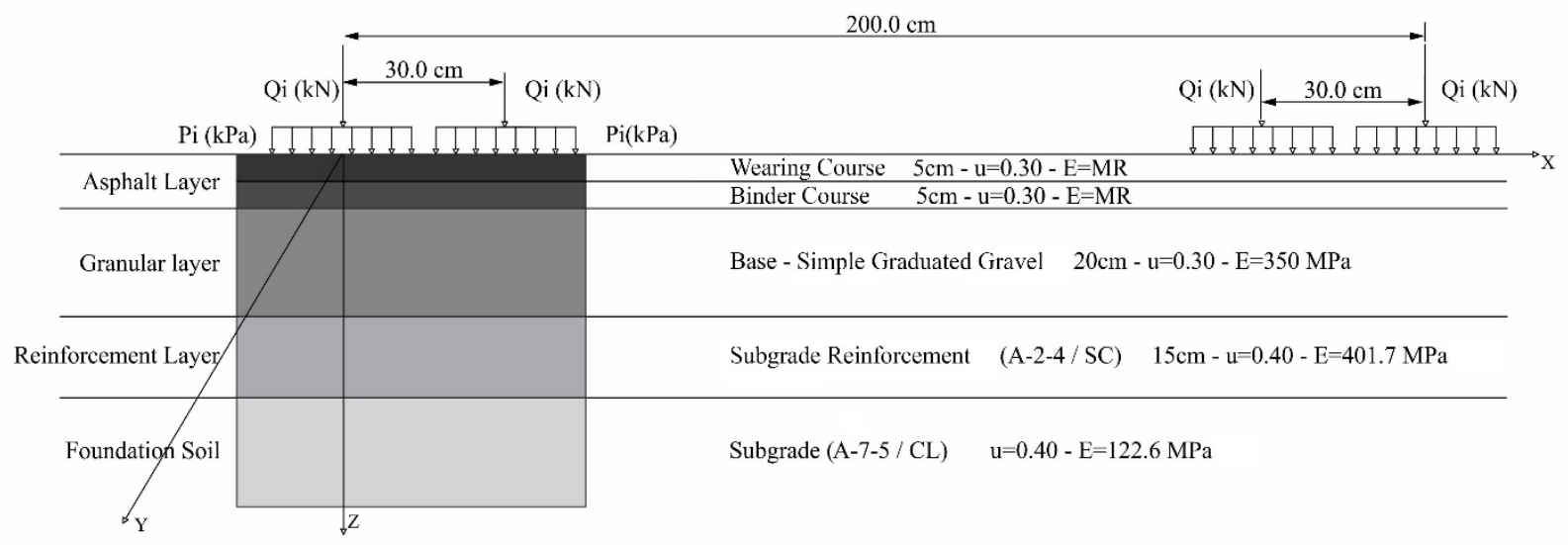

Figure 1. Reference pavement structure adopted in the structural analyses 
The characteristics of the materials used in the subgrade and reinforcement of the subgrade were extracted from the study of Carmo (1998), where the subgrade layer consisted of a clayey soil with low plasticity, which fits into the Unified Soil Classification System (USCS) and Highway Research Board (HRB), as CL and A-7-5, respectively, and for the subgrade reinforcement layer, a clayey sand soil was considered, which by the USCS and HRB classifications fits as SC and A2- 4, respectively. For the base layer, graded crushed stone, were adopted the parameters of the study by Ponte et al. (2014).

\section{RESULTS}

\subsection{Volumetric parameters of Marshall and Superpave mix design methods}

Two different gradations with different Nominal Maximum Aggregate Size (NMAS) were selected. Figure 2 shows the particle size distribution of the mixture with $12.5 \mathrm{~mm}$ NMAS, normally used as a wearing course. Figure 3 shows the 25.4 mm NMAS particle size distribution, normally used as a binder course. To enable a comparison of the volumetric properties between the mixtures, the gradations of the mixtures were selected to stay within the upper and lower limits of the Marshall and Superpave classification requirements.

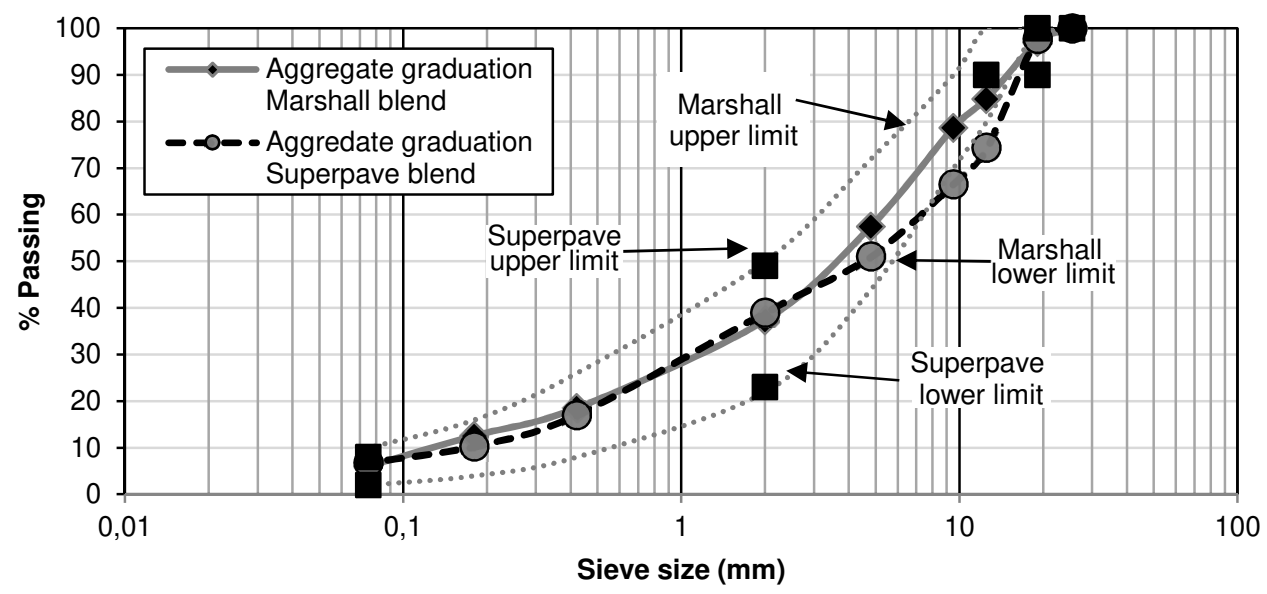

Figure 2. Aggregates gradations according to the Superpave and Marshall methods. Nominal Maximum Aggregates Size $(\mathrm{NMAS})=12.5 \mathrm{~mm}$

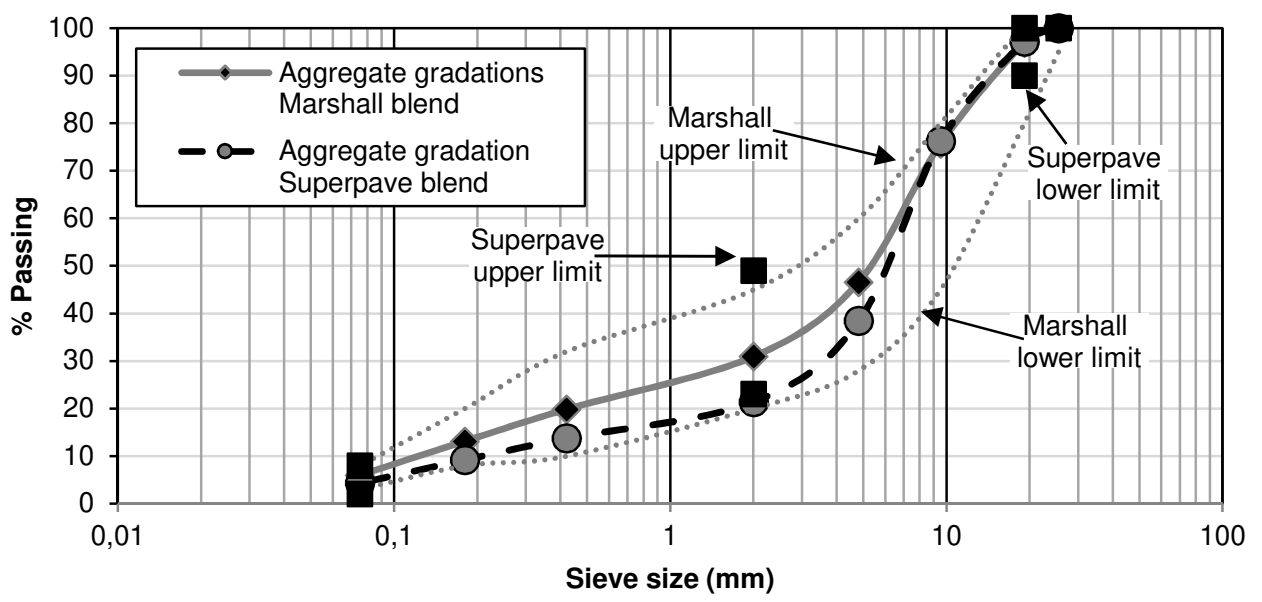

Figure 3. Aggregates gradations according to the Superpave and Marshall methods. Nominal Maximum Aggregates Size $(\mathrm{NMAS})=25.4 \mathrm{~mm}$ 
Table 1 lists the volumetric parameters of the asphalt mixtures studied in their respective optimum asphalt binder contents, as well as mechanical data of Marshall Stability and Flow are presented for these contents. The optimum asphalt binder content of the asphalt mixture of the grading envelope $\mathrm{C}$ obtained by the Marshall method is higher than that obtained by the Superpave method. This finding was also reported by Karini et al. (2012), Jitsangiam et al. (2013), and Han et al. (2016).

For the asphalt mixtures that fit the grading envelope $B$, the optimum asphalt binder content obtained by the Superpave method is higher than that obtained by the Marshall method, which although unexpected was also found by Borges (2019), who developed his research with aggregates of the same origin.

Table 1 - Volumetric and mechanical parameters of molded test specimens in the optimum asphalt binder contents

\begin{tabular}{|c|c|c|c|c|c|}
\hline Parameters & $\begin{array}{l}\text { Recommended Limits } \\
\text { ES-031 (DNIT, 2006b) }\end{array}$ & $\begin{array}{l}\text { Asphalt } \\
\text { composition } 1\end{array}$ & $\begin{array}{l}\text { Asphalt } \\
\text { composition } 2\end{array}$ & $\begin{array}{l}\text { Asphalt } \\
\text { composition } 3\end{array}$ & $\begin{array}{l}\text { Asphalt } \\
\text { composition } 4\end{array}$ \\
\hline Course & - & Wearing & Binder & Wearing & Binder \\
\hline Compaction method & - & Marshall & Marshall & Superpave & Superpave \\
\hline Grading envelope & $\mathrm{C}$ & $\mathrm{C}$ & B & C & B \\
\hline NMAS & 25.4 & 12.5 & 25.4 & 12.5 & 25.4 \\
\hline $\begin{array}{l}\text { Optimum asphalt } \\
\text { binder content (\%) }\end{array}$ & - & 4.70 & 4.20 & 4.60 & 4.85 \\
\hline VC (\%) & 3 to 5 & 4.19 & 4.49 & 4.28 & 4.75 \\
\hline VFB (\%) & 75 to 82 & 75.99 & 70.39 & 75.14 & 71.43 \\
\hline VMA (\%) & - & 15.23 & 14.71 & 15.55 & 16.48 \\
\hline Mashall Stability (kgf) & $>500$ & 524.45 & 535.34 & 867.68 & 854.93 \\
\hline Flow $(\mathrm{mm})$ & - & 3.50 & 1.20 & 4.81 & 4.70 \\
\hline $\begin{array}{l}\text { Apparent Specific } \\
\text { Mass }(\mathrm{g} / \mathrm{cm} 3)\end{array}$ & - & 2.478 & 2.480 & 2.473 & 2.458 \\
\hline TMD & - & 2.572 & 2.593 & - & - \\
\hline MMD & - & - & - & 2.588 & 2.569 \\
\hline
\end{tabular}

\subsection{Resilient Modulus Tests}

Figure 4 presents the average values of the resilient modulus determined considering specimens molded with the asphalt binder design content and specimens with variations of \pm $0.5 \%$ on the asphalt binder design content value. The asphalt mixtures designed using the Superpave method presented higher values of resilient modulus, showing that for the particularities of this study the final product resulting from Superpave method is more rigid than the final product resulting from Marshall protocol, regardless of the content of asphalt binder. This is due to the rearrangement of the particles with the rotating compaction.

In addition, it is possible to notice that, for the asphalt mixtures designed by the Marshall method, only for the grading envelope B, the increase in the asphalt binder content promoted a significant reduction in the value of the resilient modulus, since for the grading envelope $\mathrm{C}$, that reduction is within the error margin. times, need for multiple journeys, not frequent enough

For the asphalt mixtures designed by the Superpave method, the downward behavior was not observed, especially for the grading envelope B which presented increase in the resilient modulus when the optimum asphalt binder content varied by $\pm 0.5 \%$, while for the grading envelope $C$ the value of the resilient modulus decreased with a variation of $\pm 0.5 \%$ in the optimum asphalt binder content. Therefore, variations in the asphalt binder content within 
acceptable limits imply changes in the resilient modulus values for mixtures designed using the Marshall method with lower asphalt contents, such as those in grading envelope B.

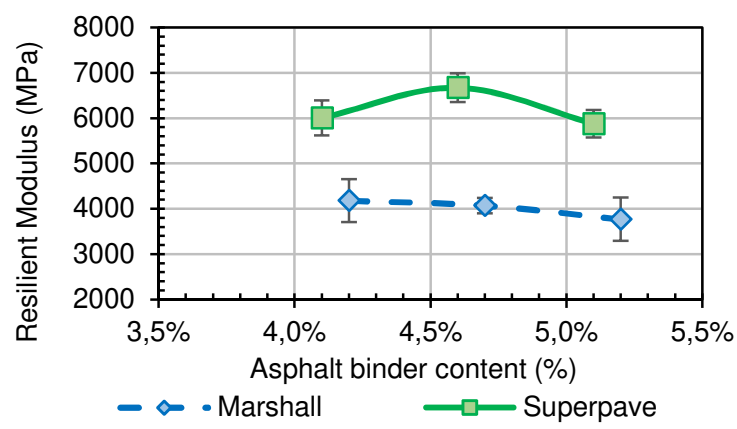

(a)

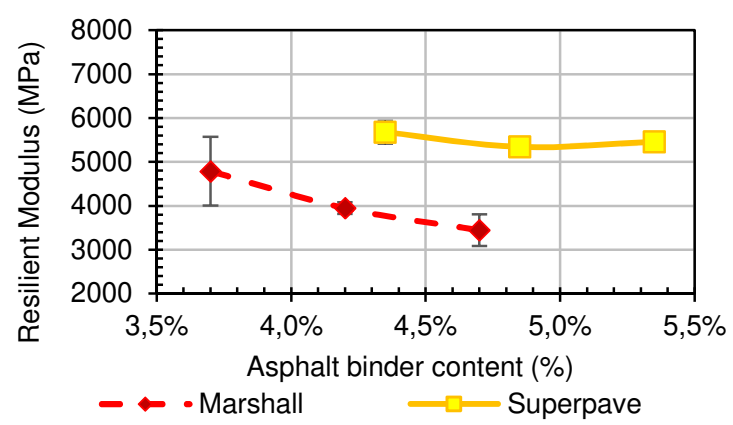

(b)

Figure 4. Mean values of the resilient modulus according to asphalt binder content: (a) for the asphalt mixtures of the grading envelope $\mathrm{C}$; (b) for the asphalt mixtures of the grading envelope $\mathrm{B}$

\subsection{Tensile Strength (Brazilian Test)}

Figure 5 shows the mean values of the tensile strength (Brazilian test) determined for the samples tested according to the optimum asphalt binder content and variations of $\pm 0.5 \%$ within that value.

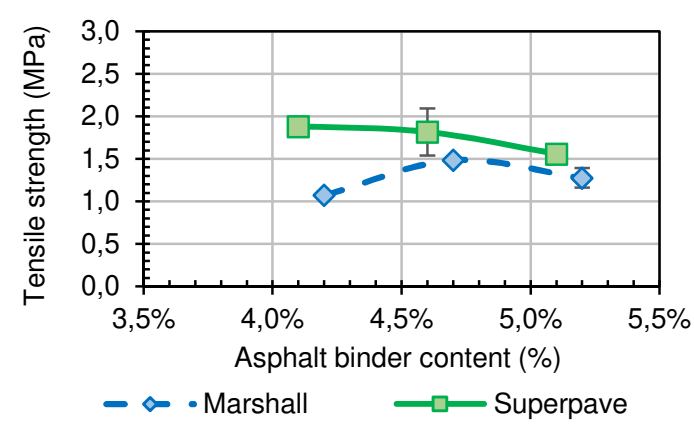

(a)

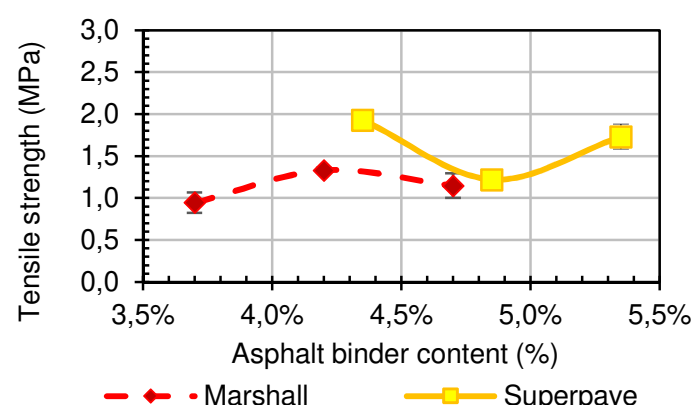

(b)

Figure 5. Tensile strength (Brazilian test) according to asphalt binder content: (a) for asphalt mixtures of the grading envelope $\mathrm{C}$; (b) for the asphalt mixtures of the grading envelope $\mathrm{B}$

The highest mean values correspond to the asphalt mixtures designed busing the Superpave method, evidencing that, for the purposes of the study, the final product resulting from the design and compaction using the Superpave method is more resistant to tension than that resulting from the Marshall protocol, regardless of the content of asphalt binder. Considering these results, it is possible to observe that regardless of the asphalt mix design method, variations in the asphalt binder content within established limits implied changes in the values of the tensile strength.

\subsection{Structural analysis of the reference pavement structure}

Eighteen structural analyses were conducted for the reference pavement structure, divided into six structures (three of them using the asphalt mixtures designed using the Marshall method and three others using the asphalt mixtures designed using the Superpave method), using the 
results of the mechanical properties of the asphalt mixtures provided for in the experimental program, considering three levels of axle load and tire inflation pressure.

Regarding the structural analyses, critical points of asphalt layer (surface course) were evaluated considering the observation that the higher tensile horizontal stresses ( $\sigma h t$ ) and recoverable vertical deflections $(\delta z)$ are under the load application points, which is why the analyses of the reference pavement structure were performed considering such points.

For the purposes of illustration, Figure 6 presents a cross section representative of horizontal stresses $(\sigma h)$ of the reference pavement structure subjected to the $80 \mathrm{kN}$ axle load and tire inflation pressure of $563 \mathrm{kPa}$, considering the asphalt layers (wearing course and binder course) designed and compacted in the optimum design content using the Marshall method (Figure 6a) and using the Superpave method (Figure 6b). In both these figures the higher tensile horizontal stresses ( $\sigma h t$ ) are in the lower fiber of the binder course and the wearing course is completely compressed.

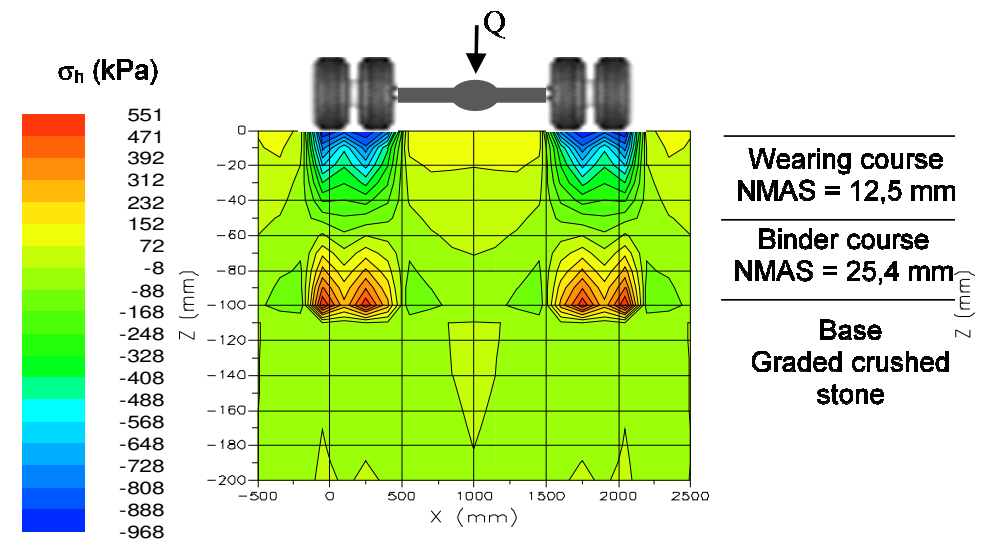

(a)

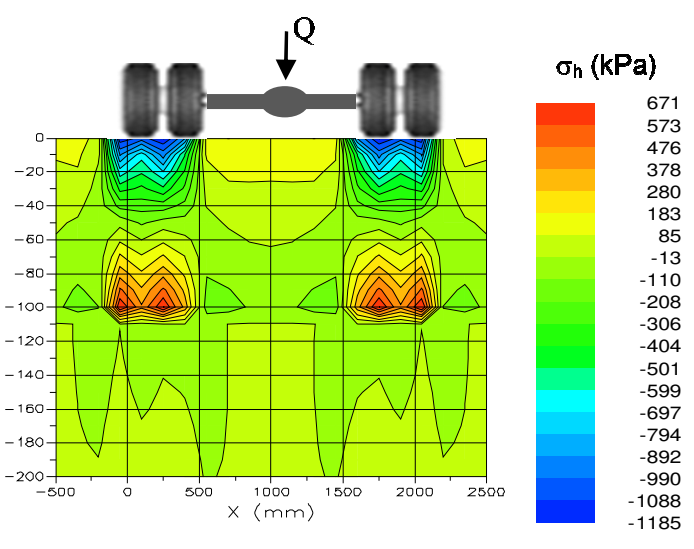

(b)

Figure 6. Horizontal stresses $(\sigma h)$ in the reference pavement structure for asphalt mixtures designed by the Marshall method (a) and Superpave method (b)

Figures 7 and 8 present the results of the horizontal stresses $(\sigma h)$ for the other scenarios considering their magnitudes in the bottom of the asphalt layers (wearing course and binder course) according to loading levels. The higher values of tensile horizontal stress ( $\sigma h t$ ) are shown in the lower fibers of the binder course composed with asphalt mixtures designed using the Superpave method.

For the asphalt mixtures designed using the Marshall method (Figure 7), the maximum tensile horizontal stresses were observed $(\sigma h t)$ in binder course $(G E=B)$ varying with the asphalt binder content (AC) and loading level was observed in each of the three asphalt pavements analyzed (Pav 1 to Pav 3), represented with a full line on the graph. For the same loading level, the maximum tensile horizontal stresses ( $\sigma h t$ ) decreases with the increasing of the asphalt binder content in the asphalt mixture. This behavior was observed at all loading levels and may be due to the fact that the resilient modulus of the asphalt mixture decreases with the increasing asphalt binder content (Figure $4 \mathrm{~b}$ ).

As the asphalt mixtures designed using the Marshall method with higher asphalt binder content presented smaller values of the resilient modulus, they are more flexible when compared with the asphalt mixtures with lower asphalt binder content. Thus, this reduction in 
maximum tensile horizontal stresses is related to the fact that the more flexible the asphalt mixtures are the more absorption and redistribution of the tensile horizontal stresses occurs, which explains the reduction observed.

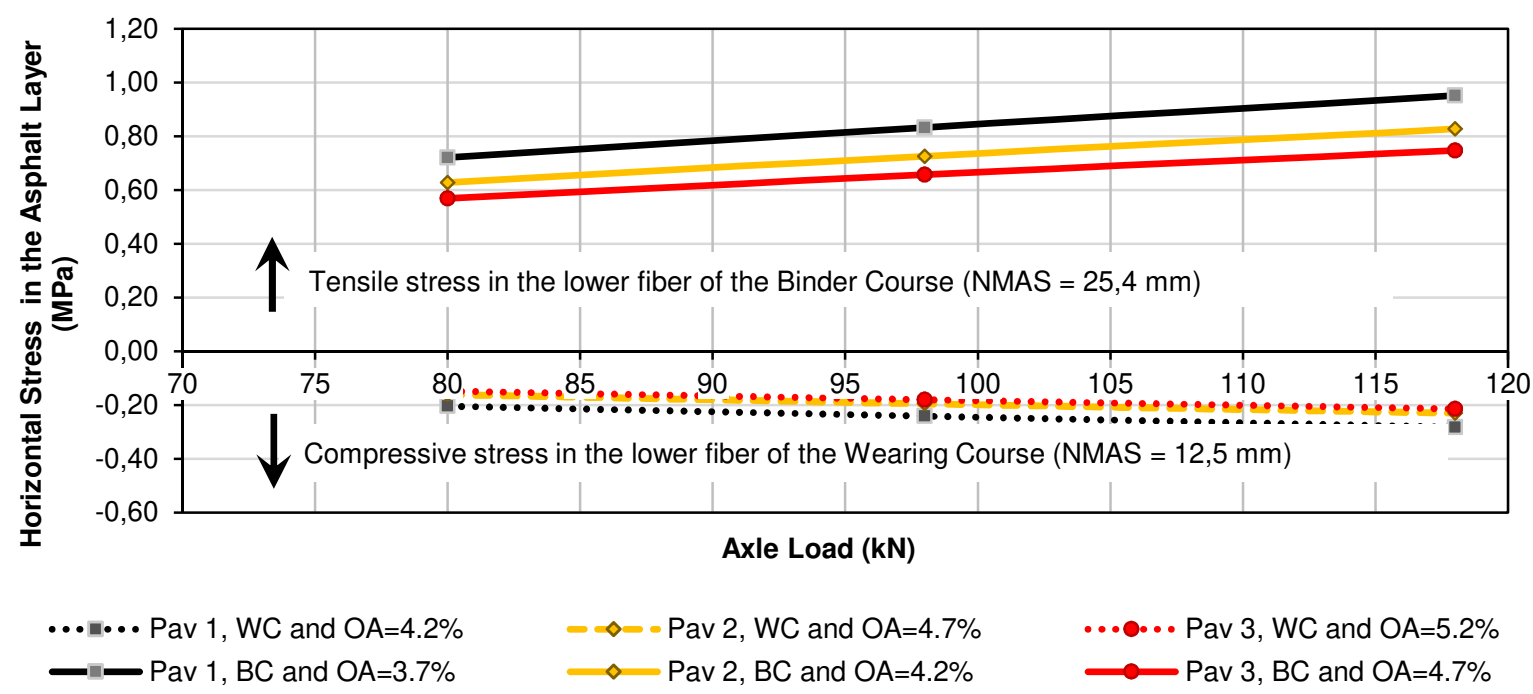

*NMAS=Nominal Maximum Aggregate Size, WC=Wearing Course, BC=Binder Course and OA=Optimum asphalt binder content

Figure 7. Horizontal stresses ( $\sigma \mathrm{h})$ in the lower fiber of the asphalt layers according to loading levels for the asphalt mixtures designed by the Marshall method

In Figure 8, the structural responses of the binder course designed using the Superpave method showed a small influence of the variation in the asphalt binder content at the maximum tensile horizontal stresses (overlapping curves). For the binder course designed using the Superpave method the maximum tensile horizontal stresses had almost no variation with the increase in the asphalt binder content for a same loading level.

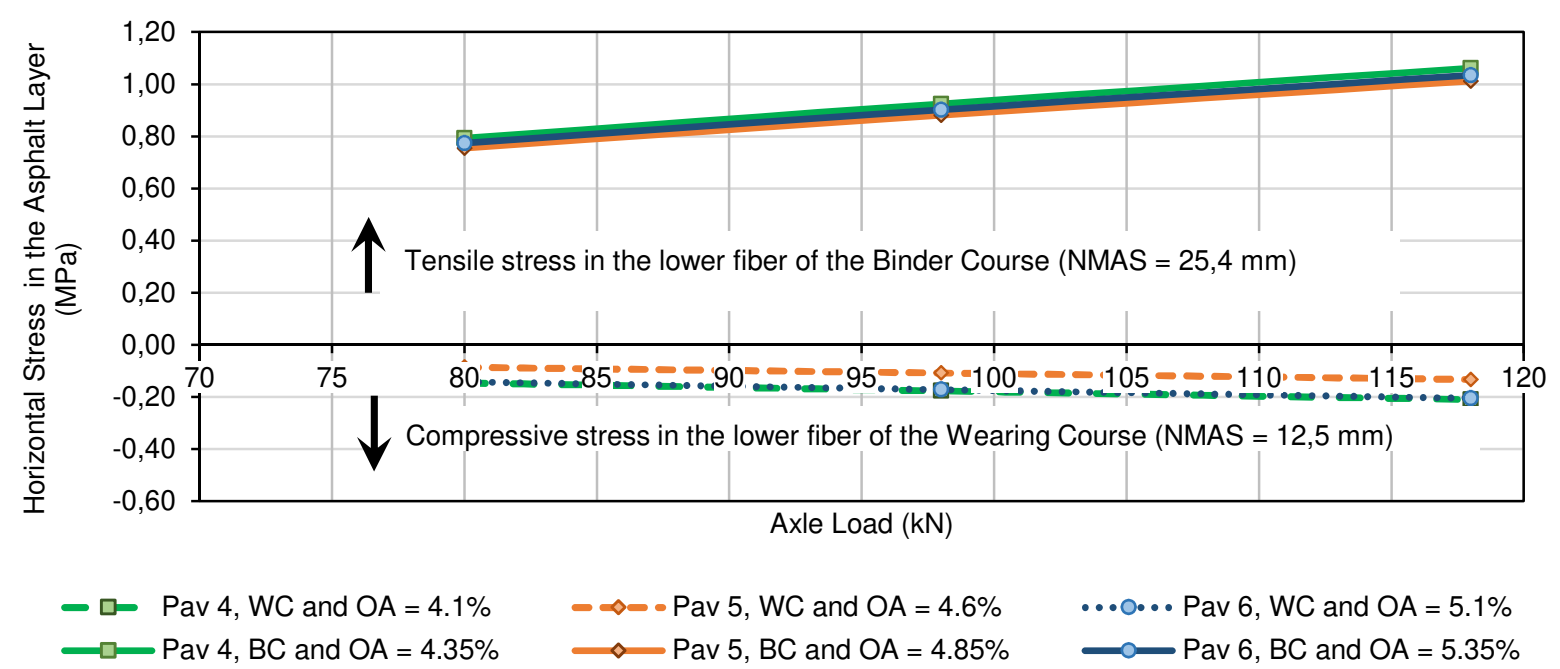

* NMAS=Nominal Maximum Aggregate Size, WC=Wearing Course, $B C=B i n d e r$ Course and $O A=O p t i m u m$ asphalt binder content

Figure 8. Horizontal stresses $(\sigma h)$ in the lower fiber of the asphalt layers according to loading levels for the asphalt mixtures designed by the Superpave method 
For the same loading level, variations in maximum tensile horizontal stress reach a maximum of $5 \%$ for the binder course designed using the Superpave method, whereas for the binder course designed busing the Marshall method these variations reach a maximum of $21 \%$. The lower structural sensitivity of the binder course designed using the Superpave method can be justified by the relative constancy of its resilient modulus with the variation in asphalt binder content as seen in Figure 4b.

Given the experimental finding that the critical tensile horizontal stresses develop at the lower edge of the binder course (grading envelope B), Figure 9 illustrates, for this edge, the variation curves of the maximum tensile stresses according to the asphalt binder content, the loading condition, and the design method of the asphalt mixtures. The corresponding tensile strength curves of the asphalt mixtures analyzed are also shown in this figure.

Despite the differences in behavior of the maximum tensile horizontal stresses for the asphalt mixtures designed by the two mix design methods analyzed, the maximum tensile horizontal stresses ( $\sigma h t$ ) calculated by the me-PADS software are inferior to the tensile strength (TS) of the asphalt mixtures studied, as in Figure 9.

Figure 10 shows the values of the recoverable vertical deflections $(\delta z)$ provided in the pavement structure for the load of $80 \mathrm{kN}$ per axle and tire inflation pressure of $563 \mathrm{kPa}$. Figure 10 a shows the vertical deflections $(\delta z)$ for the asphalt mixtures designed using the Marshall method and Figure $10 \mathrm{~b}$ the vertical deflections $(\delta z)$ for the asphalt mixtures designed using the Superpave method.

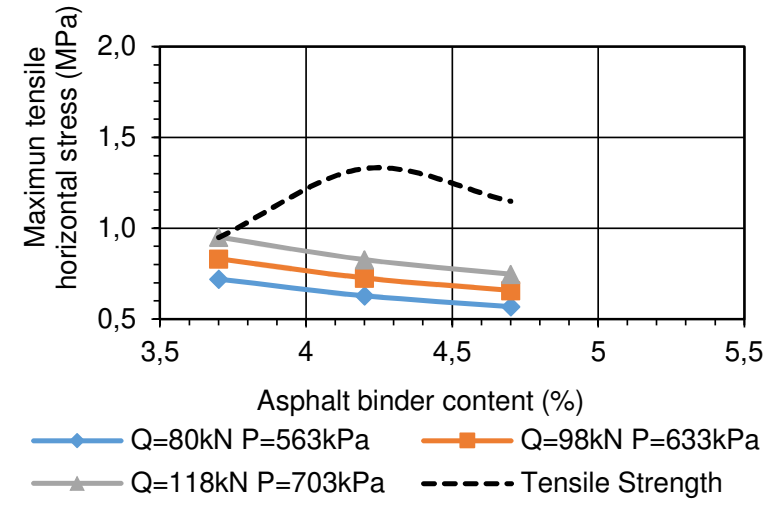

(a)

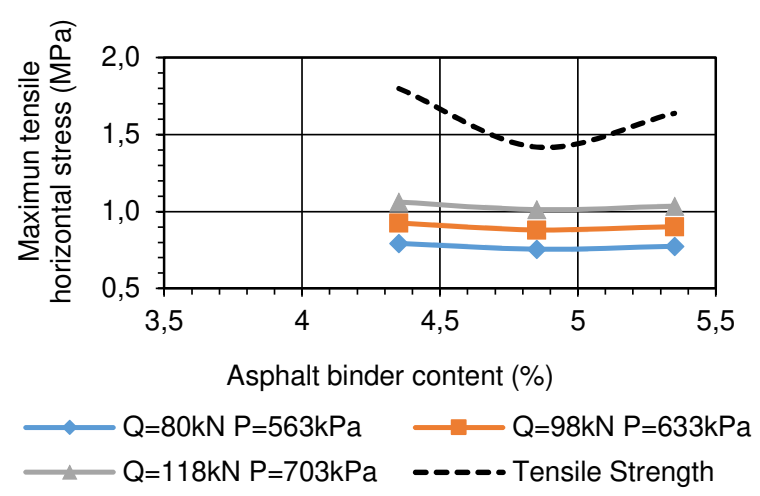

(b)

Figure 9. Tensile stresses acting on the lower edge of the binder course of the reference pavement structure according to asphalt binder content: (a) Marshall asphalt mixtures; (b) Superpave asphalt mixtures

To evaluate these maximum recoverable vertical deflection values, Figure 11 also presents the allowable vertical deflection calculated according to procedure PRO-011 (DNER, 1979) for a standard axle load of $80 \mathrm{kN}$ and for heavy traffic $(N=5 \times 107)$ according to the Brazilian highway classification of the Pavement Manual (DNIT, 2006a). The allowable vertical deflection calculated for this level of traffic is $45.18 \times 0.01 \mathrm{~mm}$ and represented by the dashed line.

In Figure 11, for the analyzed pavements, the values of resilient modulus varied with the asphalt binder contents determined using the Marshall and Superpave methods, the maximum recoverable vertical deflections are lower than the allowable levels determined for the traffic level adopted. The maximum recoverable vertical deflections presented were higher in the wearing courses designed using the Marshall method than in those designed using the 
Superpave method in about $10 \%$ for all adopted loadings which is not significant for the structural performance of the pavement.

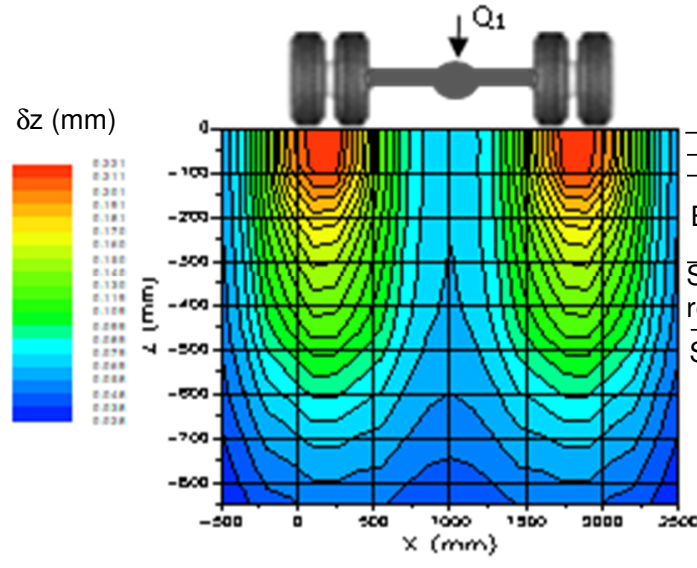

(a)

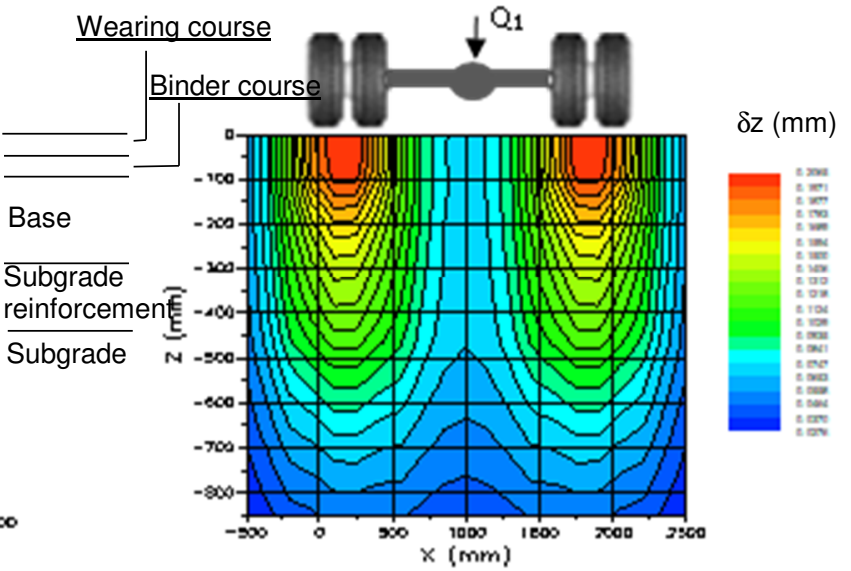

(b)

Figure 10. Recoverable vertical deflections $(\delta z)$ in the structure of the pavement analyzed for $80 \mathrm{kN}$ axle load: (a) asphalt mixtures designed by the Marshall method; (b) asphalt mixtures designed by the Superpave method

In Figure 11, for the analyzed pavements, the values of resilient modulus varied with the asphalt binder contents determined using the Marshall and Superpave methods, the maximum recoverable vertical deflections are lower than the allowable levels determined for the traffic level adopted. The maximum recoverable vertical deflections presented were higher in the wearing courses designed using the Marshall method than in those designed using the Superpave method in about $10 \%$ for all adopted loadings which is not significant for the structural performance of the pavement.

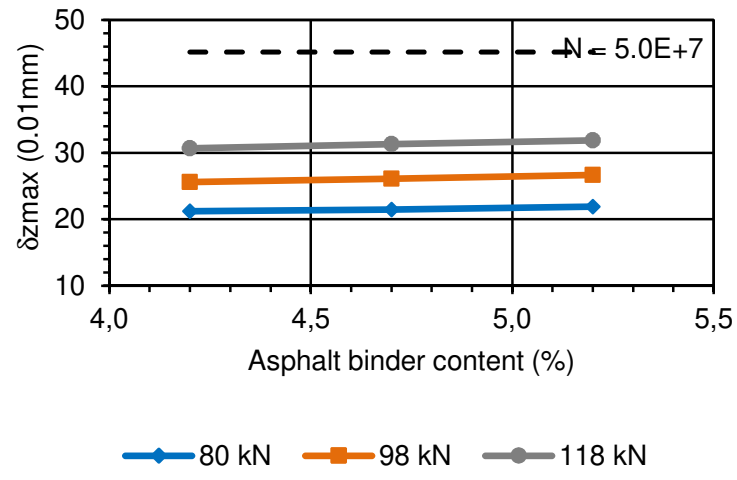

(a)

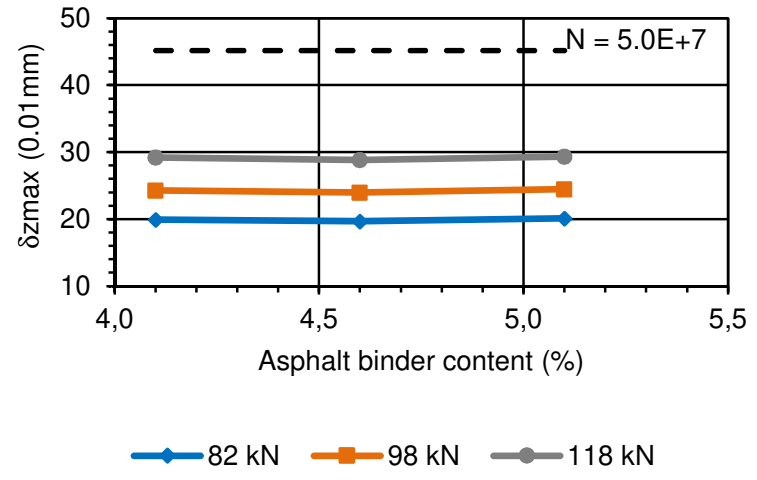

(b)

Figure 11. Maximum recoverable vertical deflections ( $\delta$ zmax $)$ in the structure of the pavement according to the asphalt binder content of asphalt mixtures: (a) Marshall method; (b) Superpave method

In Figure 11, the results of the structures composed by the asphalt mixtures designed using the Marshall method presented that the increase in the asphalt binder had produced more flexible asphalt mixtures which induces an increase in the maximum deflections for the loading levels analyzed. 
Regarding the pavement structures with asphalt mixtures designed using the Superpave method, they presented lower maximum deflections than the structures with asphalt mixtures designed using the Marshall method for the same level of loading analyzed because the asphalt mixtures designed using the Superpave method are more rigid (higher value of resilient modulus) than the asphalt mixtures designed using the Marshall method.

\section{CONCLUSIONS}

Based on the results of this research, it is possible to conclude that:

- The asphalt mixtures defined using the Marshall mix design method presented higher values of asphalt binder content and slower values of resilient modulus than the asphalt mixtures defined using de Superpave mix design method;

- The pavements with asphalt layers projected using the Marshall mix design method showed greater maximum vertical deflection recoverable and smaller horizontal stresses, for all levels of loading analyzed. This behavior it is probably associated with the fact that the asphalt mixtures projected using the Marshall method produces more flexible asphalt layers than the mixtures projected using the Superpave method. Although, it is necessary to simulate the variation in the thickness of the wearing course and binder course in order to verify if the found tendency is maintained.

- The variation on the asphalt binder content of the mixtures dosed using Marshall and Superpave method influences the asphalt mixtures mechanical proprieties. However, this variation on asphalt binder content of the mixtures does not significantly affect the structural behavior of the asphalt pavement such as the level of loadings.

- The asphalt layers designed using the Marshall method are more sensitive to variation in the asphalt binder content, which can constitute a technical differential of the asphalt mixtures designed by the Superpave method.

- As the mix design method interferes on the stiffness of the asphalt mixture and, consequently, on the behavior of the asphalt mixture as pavements layer, it is important to analyze the mix method selected during the design of asphalt pavements considering structural analyzes and evaluating parameters such as fatigue.

\section{ACKNOWLEDGEMENTS}

This study was financed in part by the Coordination for the Improvement of Higher Education Personnel - Brazil (CAPES) Finance Code 001. The authors would like thank Professor Taciano Oliveira da Silva and Professor Heraldo Nunes Pitanga of the Federal University of Viçosa, for their suggestions, which allowed to be improved and inconsistencies to be eliminated the text.

\section{REFERENCES}

Ahmad,J.; M.Y.A. Rahman; M.R. Hainin e M. Hossain (2012) Comparative evaluation of hot-mix asphalt design methods. International Journal of Pavement Engineering, v. 13, n. 2, p. 89-97. DOI: 10.1080/10298436.2011.565765.

Al-Humeidawi, B.H. (2016) Experimental characterization of rutting performance of HMA designed with aggregate gradations according to Superpave and Marshall methods. World Journal of Engineering and Technology, v. 4, p. 477-487. DOI: 10.4236/wjet.2016.43048.

Almeida, JR.; F.D. Boeira; L.P. Specht; T.C. Cervo; D.S. Pereira; R. Centofante;, V. Barbosa JR e C.C. Silva (2018) Avaliação laboratorial do tipo e teor de ligante e da granulometria na deformação permanente de misturas asfálticas. Transportes. v. 26, n. 2, p. 1-15. DOI: 10.14295/transportes.v26i2.1407.

AASHTO (2014) Designation: R 35-14. Standard Practice for Superpave Volumetric Design for Hot Mix Asphalt (HMA). American Association of State Highway and Transportation Officials.

ASI, I. M. (2007) Performance evaluation of SUPERPAVE and Marshall asphalt mix designs to suite Jordan climatic and traffic conditions. Construction and Building Materials. v. 21, p. 1732-1740. DOI: 10.1016 / j.conbuildmat.2006.05.036. 
ABNT NBR 15897 (2010) Misturas asfálticas a quente - Preparação de corpos de prova com compactador giratório Superpave. Associação Brasileira de Normas Técnicas. Rio de Janeiro.

Borges, P. R. (2019) Estudo do comportamento mecânico de misturas asfálticas à quente analisadas pelos métodos de dosagem Superpave e Marshall. Tese (doutorado). Programa Engenharia Civil. Universidade Federal de Viçosa, Viçosa. Disponível em: <https://locus.ufv.br//handle/123456789/27509> (acesso em 08/11/2021)

Carmo, C.A.T. (1998) A avaliação do módulo de resiliência através de ensaios triaxiais dinâmicos de dois solos compactados e a sua estimativa a partir de ensaios rotineiros. Dissertação (mestrado). Programada Engenharia de Transportes. Escola de Engenharia de São Carlos da Universidade de São Paulo, São Carlos. DOI: 10.11606/D.18.2018.tde-14032018-111408

DNER PRO-011 (1979) Avaliação estrutural dos pavimentos flexíveis - Procedimento B. - Procedimento de ensaio. Departamento Nacional de Infraestrutura de Transportes. Rio de Janeiro.

DNER ME-024 (1994) Pavimento - determinação das deflexões pela viga Benkelman - Método de ensaio. Departamento Nacional de Infraestrutura de Transportes. Rio de Janeiro.

DNER ME-043 (1995) Misturas betuminosas a quente - ensaio Marshall - Método de ensaio. Departamento Nacional de Infraestrutura de Transportes. Rio de Janeiro.

DNIT (2006a) Manual de Pavimentação. Departamento Nacional de Infraestrutura de Transportes. Rio de Janeiro.

DNIT ES-031 (2006b) Pavimentos flexíveis - Concreto asfáltico - Especificação de Serviço. Departamento Nacional de Infraestrutura de Transportes. Rio de Janeiro.

DNIT ME-135 (2018a) Pavimentação asfáltica - Misturas asfálticas - Determinação do módulo de resiliência - Método de ensaio. Departamento Nacional de Infraestrutura de Transportes. Rio de Janeiro.

DNIT ME-136 (2018b) Pavimentação asfáltica - Misturas asfálticas - Determinação da resistência à tração por compressão diametral - Método de Ensaio. Departamento Nacional de Infraestrutura de Transportes. Rio de Janeiro.

FHWA AS-95-003 (1995) Background of Suprpave asphalt mixture design and analysis. Federal Highway Administration. U.S. Department of Transportation. 160 p. Disponível em: https://www.fhwa.dot.gov/pavement/pubs/013177.pdf> (acesso em 08/11/2021)

Fritzen, M.A.; L.M.G. Motta (2016). Enfoque do desenvolvimento e validação da função de transferência para previsão do dano por fadiga de misturas asfálticas. 22ํㅡㄹ Encontro de Asfalto. Instituto Brasileiro de Petróleo e Gás (IBP). Rio de Janeiro. Brasil.

Gouveia, L. T.; J. L Fernandes Jr. e J. B. Soares (2007) Influência da energia de compactação no comportamento volumétrico e mecânico de misturas asfálticas. Transportes, v. XV, n.1. p. 34-41. DOI: 10.14295/transportes.v15i1.45.

Hamed, F. K. M. (2010) Evaluation of Fatigue Resistance for Modified Asphalt Concrete Mixtures Based on Dissipated Energy Concept. Thesis (Ph.D.). Darmstadt Technische Universität. Disponível em: <https://tuprints.ulb.tudarmstadt.de/id/eprint/2108> (acesso em 08/11/2021).

Han, D.; L. Wei e J. Zhang (2016) Experimental study on performance of asphalt mixture designed by different method. Procedia Engineering. v. 137, p. 407-414. D0I:10.1016/j.proeng.2016.01.275.

Jitsangiam, P.; P. Chindaprasirt e H. Nikraz (2013) An evaluation of the suitability of Suprpave and Marshall asphalt mix designs as they relate to Thailand's climatic conditions. Construction and Building Materials. v. 40, p. 961-970. DOI: 10.1016 / j.conbuildmat.2012.11.011.

Karini, S.S.; D. Golias; e C.W. Schwartz (2012) Evaluation of Superpave HMA mixture properties at the plant versus behind the paver: Statistical comparison of QC and QA data. Journal of Transportation Engineering, ASCE, v. 138, n. 7, p. 924-932. DOI: 10.1061/(ASCE) TE.1943-5436.0000399.

Khedr, S.; M. Saudy (2016) Superpave versus conventional techniques for designing normal and modified asphalt mixes. Interaction between Theory and Practice in Civil Engineering and Construction. Edited by Komurlu, R., Gurgun, A. P., Singh, A., and Yazdani, S., p. 103-108. DOI: 10.14455 / ISEC.res.2016.62

Liu, S.; W. Cao; X. Li; Z. Li e C. Sun (2018) Principle analysis of mix design and performance evaluation on Superpave mixture modified with buton rock asphalt. Construction and Building Materials. v. 176, p. 549-555. DOI: 10.1016 / j.conbuildmat.2018.05.045

Marques, G. L. O. (2004) Utilização do módulo de resiliência como critério de dosagem de mistura asfáltica, efeito da compactação por impacto e giratório. Tese (doutorado). Programa em Engenharia Civil. Universidade Federal do Rio de Janeiro. COPPE/UFRJ. Rio de Janeiro. Disponível em <http://www.coc.ufrj.br/en/documents2/doutorado/2004-2/772-geraldo-luciano-de-oliveira-marques-doutorado/file> (acesso em 08/11/2021)

Mashaan, N.S.; M.R. Karim; M.A. Aziz; M.R. Ibrahim; H.Y. Katman e S. Koting (2014) Evaluation of fatigue life of CRM-reinforced SMA and its relationship to dynamic stiffness. The Scientific World Journal. Hindawi Publishing Corporation. v. 2014, p. 111. https://doi.org/10.1155/2014/968075 (acesso em 08/11/2021)

Netto, Q. M. P. e A. C. C. Reis (2015) Análise do comportamento mecânico de misturas asfalto-borracha produzidas pelo processo úmido e seco. XXIX Congresso Nacional de Pesquisa em Transporte. ANPET, Ouro Preto. v. 1, p. 25-36. Disponível em: <http://146.164.5.73:20080/ssat/interface/content/anais_2015/TrabalhosFormatados/AC809.pdf> (acesso em $08 / 11 / 2021)$

Ponte, R.S.; V.T.F. Castelo Branco; A.S. Holanda e J.B. Soares (2014) Avaliação de diferentes metodologias para obtenção do Módulo de Resiliência de misturas asfálticas. Transportes. 22(2), p. 85-94. DOI: 10.14295/transportes.v22i2.792.

Sarsam, S. I. e H. K. Husain (2017) Influence of healing cycles and asphalt content on resilient modulus of asphalt concrete. Trends in Transport Engineering and Applications (TTEA). STM Journals. v. 4, Issue 1, p. 23-30. 
SHRP SHRP-A-407 (1994) The Superpave mix design manual for new construction and overlays. Strategic Highway Research Program. Washington, DC. Disponível em: < https://onlinepubs.trb.org/onlinepubs/shrp/SHRP-A-407.pdf> (acesso em 08/11/2021)

Vasconcelos, K. L.; J. B. Soares e L. M. Leite (2003). Efeito da densidade máxima teórica na dosagem e no comportamento mecânico de misturas asfáltica tipo CBUQ. Transportes. v. 11(2). DOI: 10.14295/transportes.v11i2.145. 